\title{
Implementasi Pembelajaran Kooperatif Berbasis Reciprocal Teaching Dengan Bantuan Peta Konsep Dalam Upaya Meningkatkan Kemampuan Koneksi Dan Pemecahan Matematik Siswa
}

\author{
Lena Rosdiana Pangaribuan ${ }^{1}$, Agusmanto Hutauruk ${ }^{2}$ \\ ${ }^{1,2}$ Universitas HKBP Nommensen Medan \\ lenapangaribuan@uhn.ac.id
}

\begin{abstract}
This research is an experimental study that examines reciprocal learning in an effort to improve the ability of connections and mathematical problem solving of students conducted at SMA Negeri 15 Medan with a sample of class XI Science as many as two classes taken randomly. The instrument used in this study was a student mathematical problem solving test in the form of multiple choices to determine the ability of connections and mathematical problem solving of students, sheets of student activity observation to determine student activity. The results of the study concluded that both mathematical connection ability, mathematical problem solving ability, or a combination of both who obtained reciprocal learning increased better than the ability to connect and mathematical problem solving abilities, or a combination of both who obtained conventional learning. Student activities that follow reciprocal learning reflect active activities, and student responses to reciprocal learning are very good. Based on the results of the study it can be concluded that the application of reciprocal learning is effective in improving connection skills, mathematical problem solving and both combined and student learning activities
\end{abstract}

\begin{abstract}
Abstrak
Penelitian ini merupakan penelitian eksperimen yang meneliti tentang pembelajaran Reciprocal dalam upaya meningkatkan kemampuan koneksi dan pemecahan masalah matematik siswa yang dilakukan di SMA Negeri 15 Medan dengan sampel kelas XI IPA sebanyak dua kelas diambil secara acak (random). Instrumen yang digunakan dalam penelitian ini adalah tes pemecahan masalah matematik siswa berbentuk pilihan berganda untuk mengetahui kemampuan koneksi dan pemecahan masalah matematik siswa, lembar observasi aktivitas siswa untuk mengetahui aktivitas siswa. Hasil penelitian dapat disimpulkan bahwa baik kemampuan koneksi matematik, kemampuan pemecahan masalah matematik, maupun gabungan keduanya yang memperoleh pembelajaran Reciprocal terjadi peningkatan yang lebih baik daripada kemampuan koneksi dan kemampuan pemecahan masalah matematik, maupun gabungan keduanya yang memperoleh pembelajaran konvensional. Aktivitas siswa yang mengikuti pembelajaran Reciprocal mencerminkan kegiatan yang aktif dan tanggapan siswa terhadap pembelajaran Reciprocal sangat baik. Berdasarkan hasil penelitian dapat disimpulkan bahwa penerapan pembelajaran Reciprocal efektif untuk meningkatkan kemampuan koneksi, pemecahan masalah matematik dan gabungan keduanya serta aktivitas belajar siswa.
\end{abstract}

Kata Kunci : $\quad$ Pembelajaran Reciprocal, Kemampuan Koneksi, Kemampuan Pemecahan Masalah, Aktivitas Aktif Siswa 


\section{Pendahuluan}

\subsection{Latar Belakang}

Pendidikan adalah alat yang tepat dalam membentuk masyarakat yang memiliki budaya sehingga dapat menyelesaikan masalah kehidupan yang dihadapinya sehari-hari. Salah satu pendidikan yang dapat dilakukan masyarakat adalah pendidikan di sekolah mulai dari jenjang SD, SMP dan SMA. Sedangkan kurikulum, pendekatan dan model yang sesuai, dan sumber daya manusia yang profesional adalah merupakan hal yang saling berkaitan untuk mencapai tujuan yang direncanakan.

Kemampuan berpikir matematik telah banyak mendapat perhatian para peneliti maupun pendidik. Banyak perhatian yang difokuskan pada batasan dalam pemahaman siswa terhadap konsep dan juga pada keterampilan berfikir, penalaran, dan penyelesaian masalah mereka dalam matematika (Henningsen dan Stein, 1997). Kemampuan berpikir matematik tingkat tinggi bersifat kompleks dan memerlukan prasyarat konsep dan proses dari yang lebih rendah baik dari segi materi maupun cara mempelajarinya sehingga dalam pembelajarannya perlu dipertimbangkan tugas serta suasana belajar yang mendukung untuk mendorong kemampuan berpikir tingkat tinggi tersebut. Hal ini menyangkut pengambilan keputusan pembelajaran yang digunakan di kelas.

Branca (dalam Utari, 1994) menyatakan bahwa pemecahan masalah matematika merupakan hal yang sangat penting sehingga menjadi tujuan umum pengajaran matematika bahkan sebagai jantungnya matematika. Lebih mengutamakan proses daripada hasil (Ruseffendi, 1991) dan sebagai fokus dari matematika sekolah dan bertujuan untuk membantu dan mengembangkan berpikir secara matematis (NCTM, 2000).

Selain kemampuan pemecahan masalah matematik, hasil pembelajaran matematika lain yang diharapkan adalah kemampuan siswa dalam melakukan koneksi matematik. Utari (2002) mengatakan bahwa koneksi matematik meliputi indikator-indikator berikut : mencari hubungan berbagai representasi konsep dan prosedur, memahami hubungan antar topik matematika, menggunakan matematika dalam bidang studi yang lain. Melalui koneksi matematika maka konsep pemikiran dan wawasan siswa akan semakin terbuka terhadap matematika, tidak hanya berfokus pada topik tertentu yang sedang dipelajari, sehingga akan menimbulkan sifat positif terhadap matematika itu sendiri.

Salah satu metode pembelajaran yang kreatif, inovatif dan efektif dalam meningkatkan kemampuan berpikir matematik tingkat tinggi adalah metode pembelajaran kooperatif. Pembelajaran kooperatif merupakan suatu metode pembelajaran yang siswanya dibentuk menjadi kelompok- kelompok kecil yang beranggotakan 4 sampai 6 orang, bekerja 
secara kolaboratif dengan struktur kelompok heterogen. (Slavin, 1995) dengan pendekatan atau serangkaian strategi yang khusus dirancang, untuk memberi dorongan kepada peserta didik agar bekerjasama selama berlangsungnya proses pembelajaran dan mencari sendiri dengan didasari pada pengetahuan yang telah dimilikinya (Sunal \& Hans, dalam Haryanto, 2000).

Implementasi metode pembelajaran ini diupayakan agar meningkatkan kemampuan koneksi dalam penumbuhan kreativitas siswa, serta kemampuan pemecahan masalah siswa sehingga menciptakan iklim yang kondusif bagi siswa dalam pengembangan daya nalar dan berpikir tingkat tinggi. Pengembangan pembelajaran ini hanya dimungkinkan jika hubungan kerjasama antar siswa terjalin dengan baik, komunikasi tercipta secara efektif serta hubungan persahabatan yang saling percaya dapat terjalin dengan baik.

Pembelajaran yang berorientasi kepada penciptaan iklim yang kondusif dapat membangun hubungan kerjasama, berbagi informasi, pengetahuan dan pengalaman siswa dengan guru. Jika syarat-syarat tersebut terpenuhi maka pengaruh pembelajaran kooperatif secara umum hasilnya positif (Salvin dalam Grouws, 1984). Oleh karena itu, peneliti langsung mengujicobakan pembelajaran kooperatif berbasis Reciprocal Teaching di kelas dengan bantuan Peta Konsep dan dibandingkan dengan pembelajaran konvensional di kelas yang lain pada sekolah yang sama.

\subsection{Rumusan Masalah}

Berdasarkan latar belakang masalah dan identifikasi masalah, yang menjadi rumusan masalah dalam penelitian ini adalah :

1. Bagaimana kemampuan koneksi matematik siswa yang menggunakan pembelajaran kooperatif berbasis Reciprocal Teaching dengan bantuan Peta Konsep ?

2. Bagaimana kemampuan pemecahan masalah matematik siswa yang menggunakan pembelajaran kooperatif berbasis Reciprocal Teaching dengan bantuan Peta Konsep ?

3. Bagaimana tanggapan siswa terhadap penerapan pembelajaran kooperatif berbasis Reciprocal Teaching dengan bantuan Peta Konsep dan soal-soal koneksi dan pemecahan masalah matematik?

\subsection{Tujuan Penelitian}

Berdasarkan rumusan masalah yang dikemukakan, maka tujuan dari penelitian ini adalah sebagai berikut : 
1. Menelaah kemampuan koneksi matematik siswa yang menggunakan pembelajaran kooperatif berbasis Reciprocal Teaching dengan bantuan Peta Konsep dan siswa yang menggunakan pembelajaran konvensional

2. Menelaah kemampuan pemecahan masalah matematik siswa yang menggunakan pembelajaran kooperatif berbasis Reciprocal Teaching dengan bantuan Peta Konsep dan siswa yang menggunakan pembelajaran konvensional

3. Mendeskripsikan tanggapan siswa terhadap penerapan pembelajaran kooperatif berbasis Reciprocal Teaching dengan bantuan Peta Konsep dan soal-soal koneksi dan pemecahan masalah matematik.

\subsection{Manfaat Penelitian}

Penelitian ini bertujuan memberikan masukan bagi kegiatan pembelajaran di kelas, khususnya dalam usaha meningkatkan kemampuan koneksi dan pemecahan masalah matematik siswa. Masukan-masukan itu diantaranya adalah :

a. Memberi informasi tentang pengaruh penerapan model pembelajaran Reciprocal Teaching terhadap peningkatan kemampuan koneksi dan pemecahan masalah matematik siswa.

b. Jika pengaruh ini positif maka model ini dapat dijadikan sebagai salah satu model pembelajaran yang digunakan dalam pembelajaran matematika.

\section{Metode Penelitian}

\subsection{Lokasi dan Waktu Penelitian}

Penelitian ini dilaksanakan di SMA Negeri 15 Medan. Adapun waktu pelaksanaan penelitian ini adalah semester ganjil Tahun Ajaran 2019/2020.

\subsection{Populasi dan Sampel}

Sugiono (2002) mengatakan populasi adalah keseluruhan objek penelitian sebagai sumber data yang memiliki karakteristik tertentu didalam penelitian. Yang menjadi populasi dalam penelitian ini adalah seluruh siswa SMA Negeri 15 Medan dengan sampel kelas XI IPA dipilih secara acak (random) sebanyak dua kelas.

\subsection{Desain Penelitian}


Desain dalam penelitian ini adalah dengan menggunakan kelompok kontrol pre-test dan post-test yang dinyatakan sebagai berikut :

\begin{tabular}{|c|c|c|c|}
\hline Kelompok & Pre-Test & Perlakuan & Post-Test \\
\hline R & O & X & O \\
\hline R & O & - & O \\
\hline
\end{tabular}

Dengan $: \mathrm{R}=$ Pengelompokan secara random

$\mathrm{O}=$ Pre-test / Post-test

$\mathrm{X}=$ Pembelajaran Reciprocal Teaching

\subsection{Instrumen Penelitian}

Instrumen yang digunakan adalah Tes (Pre-test dan Post-test), angket untuk mengetahui sikap siswa dan lembar observasi untuk mengukur tingkat aktivitas siswa selama proses pembelajaran.

\subsection{Teknik Analisis Data}

Teknik analisis data dalam penelitian ini meliputi :

1. Analisis data Kemampuan Koneksi dan Pemecahan Masalah Matematik

Berdasarkan pertanyaan nomor satu dan dua pada rumusan masalah, maka data pretest dan post-test akan dianalisis dengan statistik inferensial ANAKOVA. Analisis ini digunakan untuk menguji hipotesis dalam penelitian ini

2. Analisis data Aktivitas Aktif Siswa

Data hasil pengamatan aktivitas siswa selama kegiatan pembelajaran dianalisis dengan menggunakan persentase. Persentase pengamatan aktivitas siswa yaitu frekuensi rata-rata setiap aspek pengamatan dibagi dengan banyaknya frekuensi ratarata semua aspek pengamatan dikali $100 \%$ dengan batas toleransi $5 \%$.

\subsection{Diagram Alur Metode Penelitian}




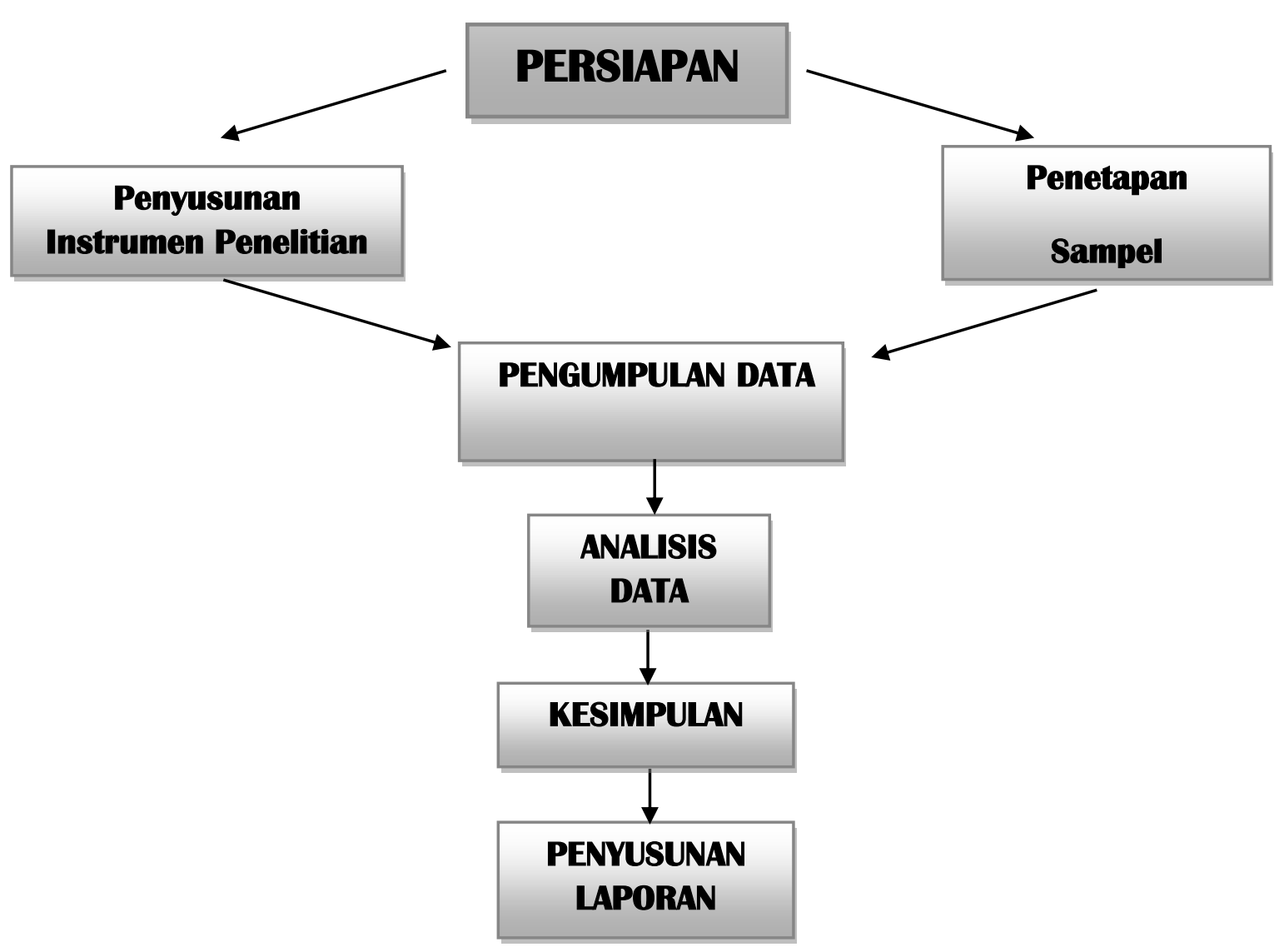




\section{Hasil Penelitian dan Pembahasan}

\subsection{Data Hasil Tes Kemampuan Koneksi dan Pemecahan Masalah Matematik}

Setelah diberikan pembelajaran pada kelas eksperimen dengan pembelajaran kooperatif dan kelas kontrol dengan pembelajaran konvensional (biasa), siswa diberi kesempatan untuk menjawab soal tes akhir (post-test). Data post-test terdiri dari data KKM (Kemampuan Koneksi Matematik) dan data KPMM (Kemampuan Pemecahan Masalah Matematik) dan gabungan kedua aspek kemapuan tersebut.

Setelah dilakukan pengolahan data post-test pada kelas eksperimen dan kontrol diperoleh skor terendah (Xmin), skor tertinggi (Xmax), skor rata-rata (Xrata-rata) dan standar deviasi (s) seperti tampak pada Tabel 3.1.

Tabel 3.1.

Rekapitulasi Data Post-test Kelas Eksperimen Dan Kelas Kontrol

\begin{tabular}{|c|c|c|c|c|c|c|c|c|c|}
\hline \multirow[t]{2}{*}{ Aspek } & \multirow{2}{*}{$\begin{array}{l}\text { Sko } \\
\mathbf{r} \\
\text { Idea } \\
\text { l }\end{array}$} & \multicolumn{4}{|c|}{ Eksperimen } & \multicolumn{4}{|c|}{ Kontrol } \\
\hline & & $\begin{array}{c}\text { Xmi } \\
\text { n }\end{array}$ & $\begin{array}{c}\mathbf{X m a} \\
\mathbf{x}\end{array}$ & $\bar{x}$ & $\mathbf{S}$ & $\begin{array}{c}\text { Xmi } \\
\text { n }\end{array}$ & $\begin{array}{c}\mathbf{X m a} \\
\mathbf{x}\end{array}$ & $\bar{x}$ & $\mathbf{S}$ \\
\hline KKM & 46 & 21 & 44 & $\begin{array}{c}31.53 \\
(68.55 \% \\
) \\
\end{array}$ & $\begin{array}{c}5.5 \\
3\end{array}$ & 20 & 42 & $\begin{array}{c}27.69 \\
(60.19 \% \\
)\end{array}$ & $\begin{array}{c}5.5 \\
6\end{array}$ \\
\hline KPMM & 32 & 4 & 26 & $\begin{array}{c}15.33 \\
(47.92 \% \\
)\end{array}$ & $\begin{array}{c}5.3 \\
2\end{array}$ & 3 & 24 & $\begin{array}{c}12.18 \\
(38.05)\end{array}$ & $\begin{array}{c}4.7 \\
9\end{array}$ \\
\hline $\begin{array}{c}\text { Gabunga } \\
n\end{array}$ & 78 & 36 & 66 & $\begin{array}{c}46.87 \\
(60.09 \% \\
)\end{array}$ & $\begin{array}{c}8.1 \\
6\end{array}$ & 24 & 66 & $\begin{array}{c}39.87 \\
(51.11 \% \\
)\end{array}$ & $\begin{array}{c}8.5 \\
2\end{array}$ \\
\hline
\end{tabular}

Tabel 3.1. diatas menunjukkan bahwa skor pencapaian KKM kelas eksperimen sebesar $68.55 \%$ dari skor ideal, lebih besar dari skor kelas kontrol dengan pencapaian sebesar $60.19 \%$ dari skor ideal. Selanjutnya pada KPMM kelas eksperimen skor pencapaiannya sebesar $47.92 \%$ dari skor ideal, juga lebih besar dari skor kelompok kontrol dengan pencapaian $38.05 \%$ dari skor ideal. Sedangkan untuk skor gabungan KKM dan KPMM skor pencapaian kelas eksperimen sebesar $60.09 \%$ dari skor ideal, lebih besar dari skor pencapaian kelas kontrol sebesar $51.11 \%$ dari skor ideal. 


\subsection{Data Aktivitas Siswa Selama Pembelajaran}

Data aktivitas siswa selama pembelajaran Reciprocal Teaching berlangsung diperoleh melalui dua orang observer/pengamat (yaitu peneliti dan 1 orang guru matematika SMA Negeri 15 Medan) setiap pertemuan/tatap muka dengan menggunakan lembar observasi. Selanjutnya pada waktu pembelajaran dilakukan observasi lalu dilakukan penilaian dengan tiga kategori penilaian yaitu Baik (B), Cukup (C), dan Kurang (K). Data dari hasil pengamatan dianalisis dengan cara mengkonversikan kategori Baik (B) ke Skor 3, Kategori Cukup (C) ke skor 2 dan Kategori Kurang (K) ke skor 1. Selanjutnya mencari nilai rata-rata dan persentase aktivitas siswa. Hasil dari analisis disajikan dalam Tabel 3.2.

Tabel 3.2.

Aktivitas Siswa Selama Pembelajaran Pada Kelas Eksperimen

\begin{tabular}{|c|c|c|c|c|c|c|c|c|c|}
\hline \multirow[b]{2}{*}{$\begin{array}{l}\mathbf{N} \\
\mathbf{0}\end{array}$} & \multirow{2}{*}{$\begin{array}{c}\text { Aspek yang } \\
\text { diamati }\end{array}$} & \multicolumn{6}{|c|}{ Rata-rata Nilai Aktivitas Siswa } & \multirow{2}{*}{$\begin{array}{l}\text { Rata- } \\
\text { rata }\end{array}$} & \multirow{2}{*}{$\begin{array}{c}\text { Kategor } \\
\text { i }\end{array}$} \\
\hline & & $\begin{array}{l}\text { Pert } \\
\text { Ke } 1\end{array}$ & $\begin{array}{l}\text { Pert } \\
\text { Ke } 2\end{array}$ & $\begin{array}{l}\text { Pert } \\
\text { Ke } 3\end{array}$ & $\begin{array}{l}\text { Pert } \\
\text { Ke } 4\end{array}$ & $\begin{array}{l}\text { Pert } \\
\text { Ke } 4\end{array}$ & $\begin{array}{l}\text { Pert } \\
\text { Ke } 5\end{array}$ & & \\
\hline 1 & 2 & 3 & 4 & 5 & 6 & 7 & 8 & 9 & 10 \\
\hline \multirow[t]{2}{*}{1} & $\begin{array}{l}\text { Keterlibatan } \\
\text { tiap anggota } \\
\text { dalam kegiatan }\end{array}$ & 3 & 3 & 2.9 & 3 & 3 & 3 & 2.98 & \multirow[t]{2}{*}{ Baik } \\
\hline & kelompok & $\begin{array}{c}100 \\
\%\end{array}$ & $100 \%$ & $\begin{array}{c}96.7 \\
\%\end{array}$ & $100 \%$ & $100 \%$ & $100 \%$ & $\begin{array}{c}99.3 \\
\%\end{array}$ & \\
\hline \multirow[t]{2}{*}{2} & \multirow{2}{*}{$\begin{array}{l}\text { Mengerjakan } \\
\text { LKS }\end{array}$} & 2.6 & 2.7 & 2.65 & 2.7 & 2.9 & 2.95 & 2.75 & \multirow[t]{2}{*}{ Baik } \\
\hline & & $\begin{array}{c}86.7 \\
\%\end{array}$ & $90 \%$ & $\begin{array}{c}88.3 \\
\%\end{array}$ & $90 \%$ & $\begin{array}{c}96.7 \\
\%\end{array}$ & $\begin{array}{c}98.3 \\
\%\end{array}$ & $\begin{array}{c}91.7 \\
\%\end{array}$ & \\
\hline \multirow[t]{2}{*}{3} & \multirow{2}{*}{$\begin{array}{l}\text { Berdiskusi } \\
\text { antara siswa } \\
\text { dengan guru }\end{array}$} & 2.3 & 2.5 & 2.6 & 2.5 & 2.7 & 2.75 & 2.56 & \multirow[t]{2}{*}{ Baik } \\
\hline & & $\begin{array}{c}76.7 \\
\%\end{array}$ & $\begin{array}{c}83.3 \\
\%\end{array}$ & $\begin{array}{c}86.7 \\
\%\end{array}$ & $\begin{array}{c}83.3 \\
\%\end{array}$ & $90 \%$ & $\begin{array}{c}91.7 \\
\%\end{array}$ & $\begin{array}{c}85.3 \\
\%\end{array}$ & \\
\hline \multirow[t]{2}{*}{4} & \multirow{2}{*}{$\begin{array}{l}\text { Berdiskusi } \\
\text { antara sesama } \\
\text { siswa }\end{array}$} & 2.6 & 2.7 & 2.7 & 2.6 & 2.7 & 2.75 & 2.68 & \multirow[t]{2}{*}{ Baik } \\
\hline & & $\begin{array}{c}86.7 \\
\%\end{array}$ & $90 \%$ & $90 \%$ & $\begin{array}{c}86.7 \\
\%\end{array}$ & $90 \%$ & $\begin{array}{c}91.7 \\
\%\end{array}$ & $\begin{array}{c}89.3 \\
\%\end{array}$ & \\
\hline \multirow[t]{2}{*}{5} & \multirow{2}{*}{$\begin{array}{l}\text { Memperhatika } \\
\text { n penjelasan } \\
\text { teman }\end{array}$} & 2.45 & 2.6 & 2.65 & 2.75 & 2.7 & 2.8 & 2.66 & \multirow[t]{2}{*}{ Baik } \\
\hline & & $\begin{array}{c}81.7 \\
\%\end{array}$ & $85 \%$ & $\begin{array}{c}88.3 \\
\%\end{array}$ & $\begin{array}{c}91.7 \\
\%\end{array}$ & $\begin{array}{c}88.3 \\
\%\end{array}$ & $\begin{array}{c}93.3 \\
\%\end{array}$ & $88 \%$ & \\
\hline 6 & Mencatat hal- & 2.45 & 2.6 & 2.65 & 2.75 & 2.7 & 2.8 & 2.66 & Baik \\
\hline
\end{tabular}




\begin{tabular}{|c|c|c|c|c|c|c|c|c|c|}
\hline & $\begin{array}{l}\text { hal yang } \\
\text { relevan dengan } \\
\text { pembelajaran }\end{array}$ & $\begin{array}{c}81.7 \\
\%\end{array}$ & $\begin{array}{c}86.7 \\
\%\end{array}$ & $\begin{array}{c}88.3 \\
\%\end{array}$ & $\begin{array}{c}91.7 \\
\%\end{array}$ & $90 \%$ & $\begin{array}{c}93.3 \\
\%\end{array}$ & $\begin{array}{c}88.7 \\
\%\end{array}$ & \\
\hline 7 & \multirow{3}{*}{$\begin{array}{l}\text { Memperhatika } \\
\text { n penjelasan } \\
\text { guru }\end{array}$} & 2.5 & 2.5 & 2.7 & 2.65 & 2.8 & 2.8 & 2.66 & \multirow[t]{3}{*}{ Baik } \\
\hline 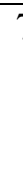 & & 83.3 & 83.3 & \multirow[t]{2}{*}{$90 \%$} & 88.3 & 93.3 & 93.3 & 88.7 & \\
\hline & & $\%$ & $\%$ & & $\%$ & $\%$ & $\%$ & $\%$ & \\
\hline \multirow[t]{4}{*}{8} & \multirow{4}{*}{$\begin{array}{l}\text { Berperilaku } \\
\text { yang tidak } \\
\text { relevan dengan } \\
\text { KBM }\end{array}$} & 0 & 0.25 & 0 & 0 & 0 & 0 & 0.04 & \multirow[t]{4}{*}{ Baik } \\
\hline & & $0 \%$ & $8.3 \%$ & $0 \%$ & $0 \%$ & $0 \%$ & $0 \%$ & 1.33 & \\
\hline & & & & & & & & $\%$ & \\
\hline & & & & & & & & & \\
\hline
\end{tabular}

$$
\begin{array}{rlll}
\text { Keterangan : } & - \text { Baik } & = & 2.45-3.0(81.7 \%-100 \%) \\
- & \text { Cukup } & = & 1.45-2.44(48.3 \%-81.3 \%) \\
- & \text { Kurang } & = & 0.0-1.44(0 \%-48 \%)
\end{array}
$$

Berdasarkan Tabel 3.2. memperlihatkan peningkatan persentase aktivitas siswa yang memperoleh pembelajaran Reciprocal Teaching, kecuali pada poin 1 pada pertemuan ketiga (ada beberapa siswa yang berhalangan hadir karena mengikuti kegiatan ekstrakurikuler) dan poin 8 pertemuan kedua (ada beberapa siswa yang belum bisa menyesuaikan), sedangkan rata-rata aktivitas siswa yang paling dominan adalah keterlibatan tiap anggota dalam kelompok yaitu 99.3\%, selanjutnya adalah mengerjakan lembar kerja siswa sebesar 91.7\%, berdiskusi dengan guru adalah $85.3 \%$, berdiskusi antara sesama siswa sebesar $89.3 \%$, memperhatikan penjelasan teman sebesar $88 \%$. Mencatat hal-hal yang relevan dengan KBM sebesar $88.7 \%$, memperhatikan penjelasan guru adalah $88.7 \%$ dan berperilaku yang tidak relevan dengan KBM sebesar $1.33 \%$.

\section{Kesimpulan}

Berdasarkan hasil temuan selama penelitian dan analisis data hasil penelitian tentang kemampuan koneksi dan pemecahan masalah matematik siswa melalui pembelajaran Reciprocal Teaching dan pembelajaran konvensional, maka peneliti memperoleh kesimpulan sebagai berikut :

1. Peningkatan kemampuan koneksi matematik siswa yang memperoleh pembelajaran Reciprocal Teaching menunjukkan hasil yang lebih baik dibandingkan dengan siswa yang memperoleh pembelajaran secara konvensional. 
2. Peningkatan kemampuan pemecahan masalah matematik siswa yang memperoleh pembelajaran Reciprocal Teaching menunjukkan hasil yang lebih baik dibandingkan dengan siswa yang memperoleh pembelajaran secara konvensional.

3. Peningkatan kemampuan gabungan koneksi dan pemecahan masalah matematik siswa yang memperoleh pembelajaran Reciprocal Teaching menunjukkan hasil yang lebih baik dibandingkan dengan siswa yang memperoleh pembelajaran secara konvensional.

\section{Referensi}

Arikunto, S. (2002). Prosedur Penelitian Suatu Pendekatan Praktek. Rineka Cipta. Jakarta

Arikunto, S. (2003). Dasar-dasar Evaluasi Pendidikan. Bumi Aksara. Jakarta

Depdiknas. (2006). Permendiknas Nomor 22 Tahun 2006 Tentang Standar Isi Sekolah Dasar. Depdiknas. Jakarta

Hergenhann, B. R. \& Mattew, H.O. (2008). Theoris of Learning. Kencana. Jakarta

Hutauruk, JB, Agusmanto. (2018). Peningkatan Kemampuan Pemecahan Masalah dan Resiliensi Matematis Mahasiswa melalui Model Problem Based Learning dengan Pendekatan Metakognitif. Disertasi Universitas Pendidikan Indonesia. Bandung

Ibrahim, M. (2000). Pembelajaran Kooperatif. Surabaya. Universitas Negeri Surabaya.

Ibrahim, M dan Nur, M. (2000). Pembelajaran Berdasarkan Masalah, Surabaya. UNESA University Press

Malone, J.A dan Krismanto, A. (1997). Indonesian Students' Attitudes and Perceptions towards Small Group Work in Mathematics. Journal of Science and Mathematics Education in Southeast Asia, Vol. XVI, No 2 tahun 1997.

Manik, Efron. (2019). Model Pembelajaran Kooperatif Dibawah Tekanan untuk meningkatkan Hasil Perkuliahan dalam Mata Kuliah Pemrograman . Jurnal Suluh Pendidikan. Vol. 7 No. 1 tahun 2019. Universitas HKBP Nommensen

Musser, G.L dan Shaughnessy, J.M. (1980). Problem Solving Strategis in School Mathematics. In Krulik, S \& Reys, R.E. (Eds) Problem Solving in School Mathematics, Virgina. NCTM.

Polya, G. (1985). How to Solve it. A New Aspect of Mathematics Method. New Jersey. Princeton University Press.

Russeffendi, H.E.T. (1998). Statistik Dasar untuk Penelitian Pendidikan. Bandung. IKIP Bandung Press. 
Sudjono, A. (1997). Pengantar Evaluasi Pendidikan. Raja Grafindo Persada. Jakarta

Sudjana. (2005). Metode Statistika. Tarsito. Bandung.

Sugiono. (2002). Statistika Untuk Penelitian. Alfabeta. Bandung.

Suharsono, N. (1991). Pengembangan Model Pembelajaran Pemecahan Masalah. Disertasi PPS UNM Malang: Tidak diterbitkan

Suherman, E dan Sukjaya, Y. (1990). Petunjuk Praktis Untuk Melaksanakan Evaluasi Pendidikan Matematika. Bandung. Wijayakusuma.

Suparno, P. (1997). Filsafat Konstruktivisme Dalam Pendidikan. Kanisius. Yogyakarta.

Wahyudin. (1999). Kemampuan Guru Matematika, Calon Guru Matematika Siswa dalam Mata Pelajaran Matematika. Disertasi tidak diterbitkan. Bandung. Program Pasca Sarjana IKIP Bandung. 